\title{
Detection of Metarhizium anisopliae var. anisopliae within infected sugarcane borer Diatraea saccharalis (Lepidoptera, Pyralidae) using specific primers
}

\author{
Ricardo Henri Rodrigues Destéfano ${ }^{1}$, Suzete A. Lanza Destéfano ${ }^{2}$ and Claudio Luiz Messias ${ }^{1}$ \\ ${ }^{1}$ Universidade Estadual de Campinas, Instituto de Biologia, Departamento de Genética e Evolução, \\ Campinas, São Paulo, Brazil. \\ ${ }^{2}$ Instituto Biológico, Laboratório de Bacteriologia Vegetal, Campinas, São Paulo, Brazil.
}

\begin{abstract}
In order to construct specific primers for the detection and identification of the entomopathogenic fungus Metarhizium within infected sugarcane borer (Diatraea saccharalis) larvae we analyzed the ITS1 -5.8S- ITS2 rDNA regions of strains and varieties of $M$. anisopliae, $M$. album and $M$. flavoviride. The PCR amplification of these regions yielded a unique fragment of approximately $540 \mathrm{bp}$ for $M$. anisopliae variety anisopliae strains $\mathrm{E}_{9}$, $\mathrm{B} / \mathrm{Vi}$ and $\mathrm{C}$ (isolated in Brazil), $600 \mathrm{pb}$ for M. a. anisopliae strain 14 (isolated in Australia), $650 \mathrm{bp}$ for the M. album and $600 \mathrm{bp}$ for $M$. flavoviride strains. The PCR products were digested with different restriction endonucleases (Afa I, Alu I, Dde I, Hae III, Hpa II and Sau 3A) and the PCR-RFLP profiles showed clear differences between the species. Sequencing of the ITS-5.8S rDNA regions allowed us to design one specific primer (ITSMet: 5' TCTGAATTTTTTATAAGTAT 3') for the Brazilian M. a. anisopliae strains ( $\mathrm{E}_{9}, \mathrm{~B} / \mathrm{Vi}$ and $\mathrm{C}$ ) and another specific primer (ITSMet14: 5' GAAACCGGGAC TAGGCGC 3') for the Australian strain (strain 14). Amplification was not observed with M. album, M flavoviride and Beauveria bassiana strains. DNA extracted from larvae infected with the Brazilian or Australian strains were tested using the specific primers designed by us to identify the fungal strains with which the larva had been infected. The correct fungal strain was successfully detected within $48 \mathrm{~h}$ of the insect having been infected, showing that this molecular technique allows rapid and secure detection and identification of $M$. anisopliae.
\end{abstract}

Key words: Metarhizium anisopliae, entomopathogenic fungi, PCR-RFLP, ITS region.

Received: April 1, 2003; Accepted: October 24, 2003.

\section{Introduction}

About $80 \%$ of the etiologic agents involved in insect diseases are fungi, encompassing 90 genera and more than 700 species. Several research groups have verified the entomopathogenicity of the Deuteromycete fungi Metarhizium anisopliae, which has become an important biocontrol agent used in the microbial control of insect pests.

The sugarcane spittlebug (Mahanarva posticata) (Homoptera, Cercopidae) causes serious losses in sugarcane crops but has been successfully controlled in northeastern Brazil using biocontrol by M. anisopliae, which has also been used in the biocontrol of other spittlebug genera (Aenolamia, Deois and Zulia) infesting pasture grasses (Onofre et al., 2002). Biological control of the sugarcane borer (Diatraea saccharalis) (Lepdoptera, Pyralidae) by

Send correspondence to Ricardo Henri Rodrigues Destéfano. Universidade Estadual de Campinas, Departamento de Genética e Evolução, Caixa Postal 6109, 13083-970 Campinas, SP, Brazil. E-mail: stefano@unicamp.br. various M. anisopliae and Beauveria bassiana isolates has been achieved by Alves et al. $(1984 ; 1985)$.

The production of mycoinsecticides is very simple, but their use as biocontrol agents depends critically on the standardization of the production runs and the stability of the mycoinsecticide under field conditions where the formulation must allow the fungus to maintain its virulence. It is also important to monitor how mycoinsecticides disseminate and survive in the environment after application (Hegedus and Khachatourians, 1996a).

There is a need for specific and sensitive systems for the detection and identification of fungi which can be used to evaluate the dispersion and environmental persistence of mycoinsecticides. Commercial implications such as the identification of existing or new fungal isolates, quality control and patent protection must also be considered because several researcher groups and commercial companies are developing production, formulation and application methods involving entomopathogens for use in the control of insect pests of agricultural and public health importance. 
The classical methods for the identification of entomopathogenic fungi are based on spore morphology, biochemical characteristics and immunological properties, but PCR and DNA sequence analysis are also being intensively used as standard tools for the detection, identification and phylogenetic analysis of many fungal species. These techniques are particularly valuable for the large number of species which are incapable of growth in the laboratory under artificial conditions and from which pure DNA is not easily obtained (Bindslev et al., 2002).

Several molecular genetic methods have been suggested as potential systems for the identification and monitoring of entomopathogenic fungi. Techniques which use DNA probes to create restriction fragment length polymorphism (RFLP) fingerprints have been used to distinguish between species (Hegedus and Khachatourians, 1993a) or individual isolates (Hegedus and Khachatourians, 1993b), although direct DNA probing methods may not exhibit the desired degree of sensitivity required for detection under field conditions (Hegedus and Khachatourians, 1996b). Other methods based on the polymerase chain reaction (PCR), such as the random amplified polymorphic DNA (RAPD) method, also exhibit the ability to discriminate between entomopathogenic fungal isolates (Jensen et al., 2001; Freire et al., 2001; Alves et al., 2001; Urtz and Rice, 1997; Fungaro et al., 1996; Leal et al., 1994; Bidochka et al, 1994) but the use of random oligonucleotide primers in the design of these systems is not useful in the detection of fungi within environmental samples which can contain a significant amount of DNA from indigenous biotic materials.

An alternative approach is to use ribosomal DNA (rDNA), an important molecular marker widely used in the identification and differentiation of species. The rDNA operon of eukaryotes can be present in multiple copies per genome, with each unit consisting of regions coding for rRNA, 18S, 5.8S and 28S genes as well as the two internal spaces (ITS 1 and ITS 2) between these regions, each rDNA unit being separated by one intergenic space (IGS). The rDNA unit presents sequence variations which may be used in systematic studies at different taxonomic levels (Fouly et al., 1997; Argentina, 1999). The rDNA 18S and 28S regions are the most conserved units, and may be used in differentiating genera and species, while the ITS and IGS spacer regions have accumulated more variability and are better used to differentiate species or strains within the same species (Esteve-Zarzoso et al., 1999).

In the study reported in this paper we sequenced the ITS1 -5.8S- ITS2 region of various Metarhizium strains and designed specific primers for the detection and identification of $M$. anisopliae within infected $D$. saccharalis larvae.

\section{Material and Methods}

\section{Fungal strains}

The Metarhizium album strain was supplied by Dr. Myrian Tigano-Milani (Cenargen-EMBRAPA, Brasília, DF, Brazil) while the other Metarhizium and Beauveria bassiana strains were obtained from the Germplasm Bank of the Laboratório de Genética de Microrganismos Entomopatogênicos (Departamento de Genética e Evolução, Instituto de Biologia, Universidade Estadual de Campinas UNICAMP, Campinas, SP, Brazil. All strains are listed in Table 1.

Each fungal strain was individually grown on rice medium ( $50 \mathrm{~g}$ of food grade rice plus $40 \mathrm{~mL}$ distilled water, sterilized at $121^{\circ} \mathrm{C}$ for $20 \mathrm{~min}$ ) for ten days at $28^{\circ} \mathrm{C}$.

Table 1 - Fungal strains used in this study and their insect hosts.

\begin{tabular}{|c|c|c|c|}
\hline Fungal Strain & Host insect & Source & GenBank accession $n$. \\
\hline \multicolumn{4}{|c|}{ Metarhizium anisopliae variety anisopliae } \\
\hline $\mathrm{E}_{9}$ & Deois flavopicta (Homoptera: Cercopidae) & Brazil & AY 373632 \\
\hline B/Vi ( $E_{9}$ auxotrophic mutant tya $\left.{ }^{-}\right)$ & & Brazil & AY 373633 \\
\hline $\mathrm{C}$ & Mahanarva posticata (Homoptera: Cercopidae) & Brazil & AY 373634 \\
\hline 14 & unknown & Australia & AY 375445 \\
\hline \multicolumn{4}{|l|}{ Metarhizium album } \\
\hline 201 (ARSEF 2082) & Cofana spectra (Homoptera: Cicadellidae) & Indonesia & AY 375446 \\
\hline \multicolumn{4}{|l|}{ Metarhizium flavoviride } \\
\hline 204 (ARSEF 2024) & Otiorhynchus sulcatus (Coleoptera: Curculionidae) & France & AY 375447 \\
\hline 209 (ARSEF 2133) & Ceutorhynchusmacula alba (Coleoptera: Curculionidae) & Czechoslovakia & AY 375449 \\
\hline \multicolumn{4}{|l|}{ Beauveria bassiana } \\
\hline ARSEF 959 & Spodoptera frugiperda (Lepdoptera: Noctuidae) & Brazil & \\
\hline ARSEF 2253 & Autographa gamma (Lepdoptera: Noctuidae) & France & \\
\hline ARSEF 2629 & Diatraea saccharalis (Lepdoptera: Pyralidae) & Brazil & \\
\hline
\end{tabular}

ARSEF: Agricultural Research Service of Entomopathogenic Fungi. 


\section{Host insects and infection procedure}

Third instar sugarcane borer (Diatraea saccharalis) larvae (produced from stock cultures maintained in CTC/ COPERSUCAR, Piracicaba, SP, Brazil) were infected by allowing them to walk over the sporulating fungi for $10 \mathrm{~min}$ so that each larva received a potential inoculum of about $3.5 \times 10^{6}$ conidia. Each infected larva was placed in a plastic plate containing a small piece of sugarcane stalk and the plates kept at $28{ }^{\circ} \mathrm{C}$ and $80-100 \%$ relative humidity. Twenty-four larvae per treatment were collected $48 \mathrm{~h}$ postinfection, sacrificed immediately by freezing at $-20^{\circ} \mathrm{C}$ for $4 \mathrm{~h}$ and transferred to $-80^{\circ} \mathrm{C}$. This procedure was repeated for each fungal strain.

To remove external fungi, the surface of the dead larvae were carefully washed, with gentle agitation, three times in $2.5 \%(\mathrm{v} / \mathrm{v})$ sodium hypochloride solution for $10 \mathrm{~min}$, three times in $0.1 \%(\mathrm{v} / \mathrm{v})$ Tween 80 solution and a further three times with $0.85 \%(\mathrm{w} / \mathrm{v})$ sodium chloride solution and the individual larva placed on sterilized filter paper and dried in a laminar flow chamber. To confirm the effectiveness of the surface disinfection process $0.1 \mathrm{~mL}$ of the effluent from the last wash was inoculated onto agar plates of the complete medium of Pontecorvo et al. (1953) and the plates incubated for up to ten days at $28^{\circ} \mathrm{C}$. Infection of the larvae was confirmed by placing some washed larvae onto the surface of the same medium and incubating the plate under the same conditions.

The dead, washed, cleaned and dried larvae were stored in Petri dishes in an ultra-freezer at $-80{ }^{\circ} \mathrm{C}$. Noninfected sugarcane larvae were washed and stored in the same way and the extracted DNA used as a control.

\section{DNA extraction and amplification}

Genomic DNA was extracted from fungal mycelia, non-infected larvae and infected larvae $(48 \mathrm{~h}$ postinfection) as described by Garber and Yoder (1983). The ITS regions were amplified using the ITS1 and ITS4 primers (White et al., 1990). The PCR reactions were carried out using a PTC 200 DNA Thermal Cycler (MJ Research) using $25 \mu \mathrm{L}$ reaction volumes, each containing $100 \mathrm{ng}$ of template DNA, 1X Taq buffer, $0.4 \mathrm{mM}$ of each primer ITS1 and ITS4, $200 \mathrm{mM}$ of dNTP mix, $0.1 \%$ bovine serum albumin (BSA) and $1 \mathrm{U}$ of Taq DNA polymerase (GenotaqGENON) using one cycle of $3 \mathrm{~min}$ at $95^{\circ} \mathrm{C}$ followed by 32 cycles of $1 \mathrm{~min}$ at $94{ }^{\circ} \mathrm{C}, 1 \mathrm{~min}$ at $50^{\circ} \mathrm{C}$ and $1 \mathrm{~min}$ at $72{ }^{\circ} \mathrm{C}$ with a final extension of $3 \mathrm{~min}$ at $72{ }^{\circ} \mathrm{C}$.

\section{RFLP analysis of PCR amplified DNA}

The PCR products $(3 \mu \mathrm{L})$ were individually digested with restriction endonucleases Afa I, Alu I, Dde I, Hae III, Hpa II and Sau 3A I under conditions specified by the manufacturer (Amersham Biosciences) and the restriction fragments separated by electrophoresis in 3\% agarose gels using 1X TAE buffer (Sambrook et al., 1989). The gels were stained with ethidium bromide and then visualized under UV. The molecular weights of the fragments were determined by comparison with a 100 bp DNA ladder (Amersham Biosciences).

\section{Sequence analysis}

The ITS1 - 5.8S - ITS2 amplified products (about $540 \mathrm{bp}$ ) were purified with the GFX PCR DNA and Gel Band Purification kit (Amersham Biosciences) and sequenced in an automated system (ABI 377, Perkin Elmer, Foster City, CA, USA). The sequences were aligned using the ClustalW (http://www.ebi.ac.uk/clustalw) program and compared with those available in the GenBank data base for M. a. anisopliae (accession numbers AF516295 and AF134150), M. album (AF137067), M. flavoviride (AF138269) and Beauveria bassiana (BBA345090) using the Genetic Data Environment (GDE) software version 2.2 and phylogenetic trees constructed using the Neighbor-joining method (gopher://megasun.bch. umontreal.ca: 70/11/GDE).

\section{Primer design and PCR conditions for Metarhizium anisopliae}

We found that the sequenced regions of the products from the Brazilian M. a. anisopliae strains $\mathrm{E}_{9}, \mathrm{~B} / \mathrm{Vi}$ and $\mathrm{C}$ differed from those of the Australian M. a. anisopliae strain 14 and this allowed us to design a specific primer for each of these distinct groups based on the location of the differences in the ITS1 - 5.8 S - ITS2 sequences. Two Oligonucleotide primers were designed: a 20 mers oligonucleotide primer (5' TCTGAATTTTTTATAAGTAT 3'), which we named ITSMet, for the $\mathrm{E}_{9}, \mathrm{~B} / \mathrm{Vi}$ and $\mathrm{C}$ strains and an 18 mers primer (5' GAAACCGGGACTAGGCGC 3'), which we named ITSMet14, for strain 14. These primers were used in PCR reactions with DNAs from the different Metarhizium strains, the ITS4 oligonucleotide being used as the reverse primer and primer specificity checked by comparison with available GenBank/EMBL/DDBJ data base sequences.

The DNAs from M. a. anisopliae strains $\mathrm{E}_{9}, \mathrm{~B} / \mathrm{Vi}$ and $\mathrm{C}$ and 14 were used as targets in PCRs performed in $25 \mu \mathrm{L}$ reaction mixtures containing $1 \mathrm{X}$ Taq buffer, $0.6 \mathrm{mM}$ of the ITSMet primer, $0.4 \mathrm{mM}$ of the ITS4 primer, $0.1 \%$ BSA (w/v), $0.2 \mathrm{mM}$ of dNTP mix and 1U of Taq DNA polymerase (Genotaq-GENON). The ITSMet/ITS4 set primer amplification reaction conditions consisted of $3 \mathrm{~min}$ at $95^{\circ} \mathrm{C}$ followed by 32 cycles of $1 \mathrm{~min}$ at $94{ }^{\circ} \mathrm{C}, 1 \mathrm{~min}$ at $46^{\circ} \mathrm{C}$ and $1 \mathrm{~min}$ at $72^{\circ} \mathrm{C}$ with a final extension of $3 \mathrm{~min}$ at $72^{\circ} \mathrm{C}$. The reaction conditions for the ITSMet14/ITS4 primer set were 3 min at $95{ }^{\circ} \mathrm{C}$ followed by 32 cycles of 1 min at $94{ }^{\circ} \mathrm{C}$, $1 \mathrm{~min}$ at $61^{\circ} \mathrm{C}$ and $1 \mathrm{~min}$ at $72^{\circ} \mathrm{C}$ with a final extension of $3 \mathrm{~min}$ at $72{ }^{\circ} \mathrm{C}$. The products were visualized under UV light in $1 \%$ agarose gels stained with ethidium bromide. 


\section{Detection of Metarhizium anisopliae within infected insects}

The ability of the PCR-based system to identify $M$. anisopliae within infected larvae was determined using total DNA extracted from infected larvae $48 \mathrm{~h}$ after inoculation with $M$. a. anisopliae. PCR was conducted either with the ITSMet/ITS4 or ITSMet14/ITS4 primer sets according to the strain involved, DNAs from pure cultures of the different Metarhizium strains were used as controls and DNA from non-infected larvae was also tested. The presence of Metarhizium strains within infected larvae was confirmed by restriction profiling (using the endonucleases Afa I, Alu I, Dde I, Hae III, Sau 3A I and Taq I) of the PCR products obtained from infected larvae and pure cultures of the fungi.

\section{Results}

\section{PCR-RFLP of the ITS1 - 5.8S - ITS2 sequence}

The amplification of the ITS region resulted in a single product for all isolates. The size of the product was about 540 bp for $M$. a. anisopliae strains $\mathrm{E}_{9}, \mathrm{~B} / \mathrm{Vi}$ and $\mathrm{C}$, $600 \mathrm{bp}$ for M. a. anisopliae strain 14, $650 \mathrm{bp}$ for the $M$. album strain and $600 \mathrm{bp}$ for M. flavoviride strains. The PCR products digested with the restriction enzymes Afa I, Alu I, Dde I, Hae III, Hpa II and Sau 3A I (Figure 1, Table 2) showed distinct RFLP patterns for different strains. Digestions with $A f a$ I generated fragments of from 100 to $600 \mathrm{bp}$ while $A l u$ I yielded fragments of from 100 to $650 \mathrm{bp}$. Digestions with Hae III produced fragments ranging from 100 to $450 \mathrm{bp}$ and Dde I fragments of from 150 to $450 \mathrm{bp}$, but with slightly different profiles for different strains. The Hpa II digestions revealed fragments ranging from 100 to $370 \mathrm{bp}$, showing clear differences between $M$. anisopliae, M. album and M. flavoviride. Fragments from 100 to $410 \mathrm{bp}$ were obtained in the Sau 3A I digestions and differentiation between the three Metarhizium species was again evident. The Australian strain of M. a. anisopliae (strain 14) showed a distinct profile in comparison with the other strains of the same species with all restriction enzymes tested, representing a separate group.

\section{Phylogenetic analysis of the ITS sequence}

The alignments of the nucleotide sequences of the ITS1 -5.8S- ITS2 regions of the strains investigated by us with GenBank ITS sequences for the same region and species of fungi are shown in Figure 2. The alignments and phylogenetic analysis (Figure 3 ) confirmed the taxonomic identity of the strains used in our study, with M. album strain 201 grouping with the GenBank M. album sequence AF137067 while M. flavoviride strains 204 and 209 grouped with the GenBank $M$. flavoviride sequence AF138269, although strain 204 was phylogenetically more distantly related. The $M$. a. anisopliae ITS sequences from strains $\mathrm{E}_{9}, \mathrm{~B} / \mathrm{Vi}$ and $\mathrm{C}$ were phylogenetically identical to

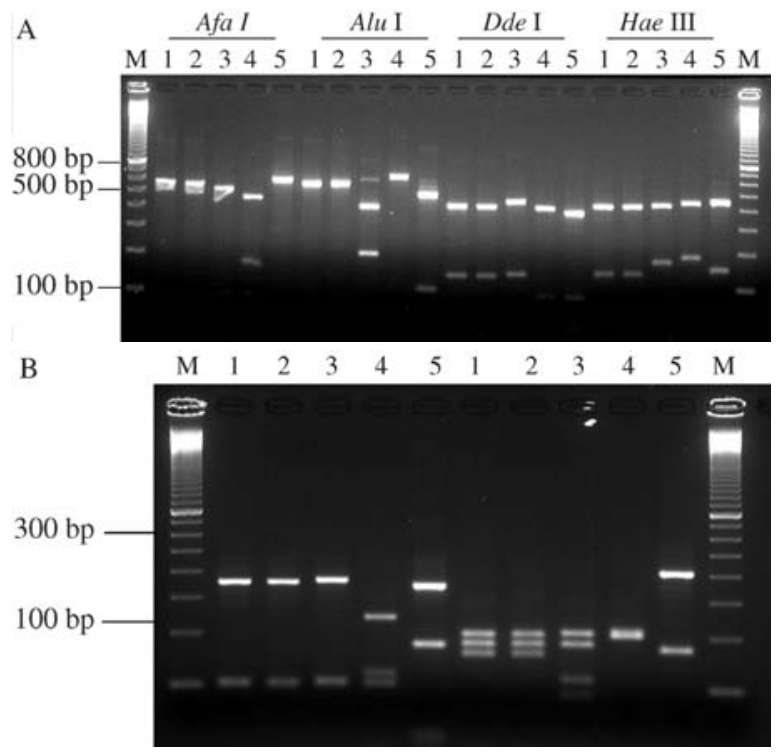

Figure 1 - PCR-RFLP of the ITS1 - 5.8S - ITS4 region digested with (A) Afa I, Alu I, Dde I and Hae III, and (B) Hpa II e Sau 3A I. 1 = Metarhizium anisopliae var. anisopliae strain $\mathrm{E}_{9} ; 2=M$. a. anisopliae strain $\mathrm{C} ; 3=M$. $a$. anisopliae strain 14; 4 = Metarhizium album strain 201; (5) Metarhizium flavoviride strain 204. M=100 bp marker.

Table 2 - RFLP profiles produced by digestions of the ITS-PCR products with different restriction enzymes.

\begin{tabular}{|c|c|c|}
\hline Restriction enzymes & Fragments (bp) & Fungal strains \\
\hline \multirow[t]{4}{*}{ Afa I } & 540 & M. anisopliae: $\mathrm{E} 9, \mathrm{~B} / \mathrm{Vi}, \mathrm{C}$ \\
\hline & 100,500 & M. anisopliae: 14 \\
\hline & 180,450 & M. album: 201 \\
\hline & 600 & M. flavoviride: 209 \\
\hline \multirow[t]{4}{*}{ Alu I } & 540 & M. anisopliae: $\mathrm{E} 9, \mathrm{~B} / \mathrm{Vi}, \mathrm{C}$ \\
\hline & 200,400 & M. anisopliae: 14 \\
\hline & 650 & M. album: 201 \\
\hline & 100,450 & $\begin{array}{l}\text { M. flavoviride: } 204 \text { and } \\
209\end{array}$ \\
\hline \multirow[t]{4}{*}{ Dde I } & 150,400 & M. anisopliae: $\mathrm{E} 9, \mathrm{~B} / \mathrm{Vi}, \mathrm{C}$ \\
\hline & 180,430 & M. anisopliae: 14 \\
\hline & 190,450 & M. album: 201 \\
\hline & 160,450 & $\begin{array}{l}\text { M. flavoviride: } 204 \text { and } \\
209\end{array}$ \\
\hline \multirow[t]{4}{*}{ Hae III } & 120,410 & M. anisopliae: E9, B/Vi, C \\
\hline & 130,450 & M. anisopliae: 14 \\
\hline & 100,410 & M. album: 201 \\
\hline & 100,390 & $\begin{array}{l}\text { M. flavoviride: } 204 \text { and } \\
209\end{array}$ \\
\hline \multirow[t]{4}{*}{ Hpa II } & 100,360 & M. anisopliae: $\mathrm{E} 9, \mathrm{~B} / \mathrm{Vi}, \mathrm{C}$ \\
\hline & 100,370 & M. anisopliae: 14 \\
\hline & $100,120,250$ & M. album: 201 \\
\hline & $100,160,340$ & M. flavoviride: 209 \\
\hline \multirow[t]{5}{*}{ Sau 3A I } & $170,190,210$ & M. anisopliae: $\mathrm{E} 9, \mathrm{~B} / \mathrm{Vi}, \mathrm{C}$ \\
\hline & $100,120,190,2$ & M. anisopliae: 14 \\
\hline & 10 & M. album: 201 \\
\hline & 210 & M. flavoviride: 209 \\
\hline & 180,410 & \\
\hline
\end{tabular}


each other and to GenBank M. a. anisopliae sequences AF516295 and AF134150, while M. a. anisopliae strain 14 from Australia formed a separate group, supporting the high level of polymorphy detected in the PCR-RFLP experiments. The $B$. bassiana strains grouped with the GenBank sequences (Figure 3).

\section{Design of new $M$. anisopliae primers}

As pointed out in the Material and Methods section, the presence of sequence differences in the PCR products of the ITS-5.8 S rDNA regions meant that the specificity of the system to generate primers capable of recognizing regional differences in the ITS sequences of the strains could be increased by sequencing the PCR products from the M. a. anisopliae, M. album and M. flavoviride strains and comparing the sequences to each other. We observed some differences in the sequenced regions of the products from the Brazilian M. a. anisopliae (strains $\mathrm{E}_{9}, \mathrm{~B} / \mathrm{Vi}$ and C) and the Australian M. a. anisopliae strain 14 which allowed us to develop a specific primer for each of these distinct

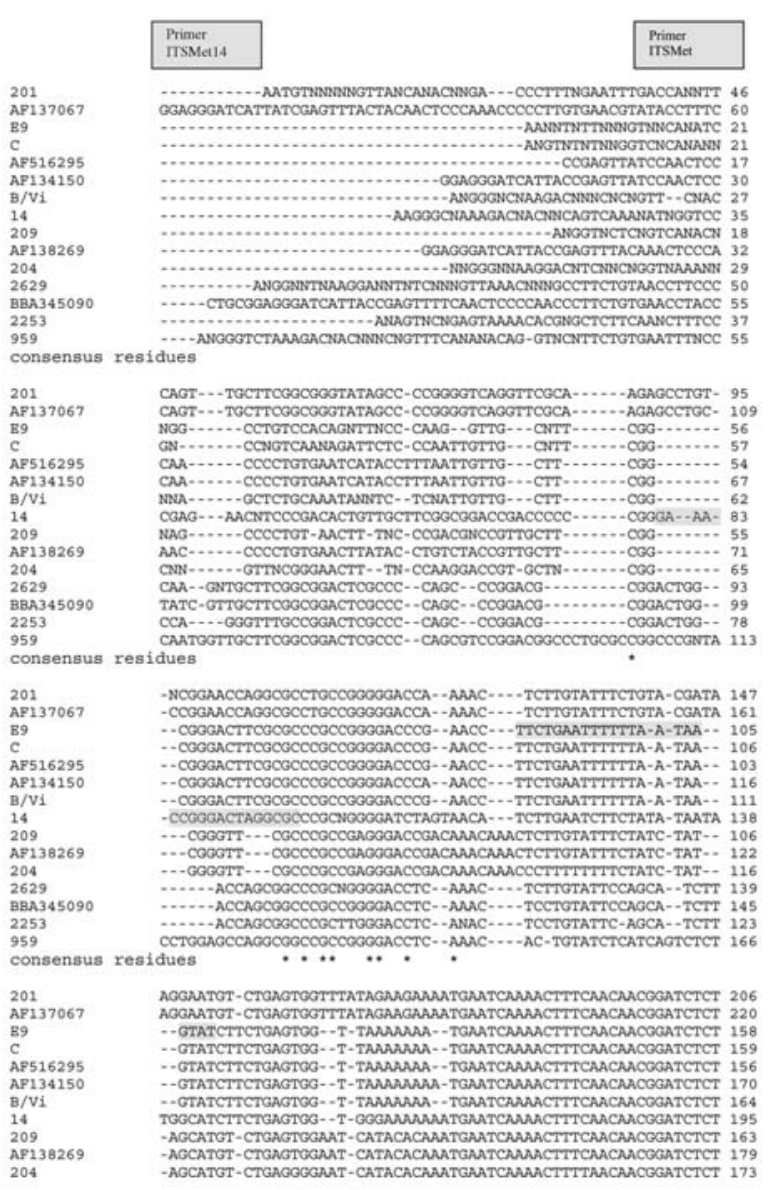

groups, ITSMet for the Brazilian strains and ITSMet14 for Australian strain.

With all the M. a. anisopliae strains studied by us the ITSMet/ITS4 primer set yielded a specific 440 bp PCR product. Although this set has been developed only to Brazilian strains, the Australian strain 14 manifested a lowintensity band in the gels. The ITSMet14/ITS4 primer set produced a $490 \mathrm{bp}$ fragment only from strain 14 . Neither of these primers produced amplified products with any of the M. album, M. flavoviride or Beauveria bassiana strains (Figure 4).

\section{Detection of Metarhizium anisopliae within infected insects}

The presence of Metarhizium strains within infected larvae was confirmed by the restriction profiles of the PCR

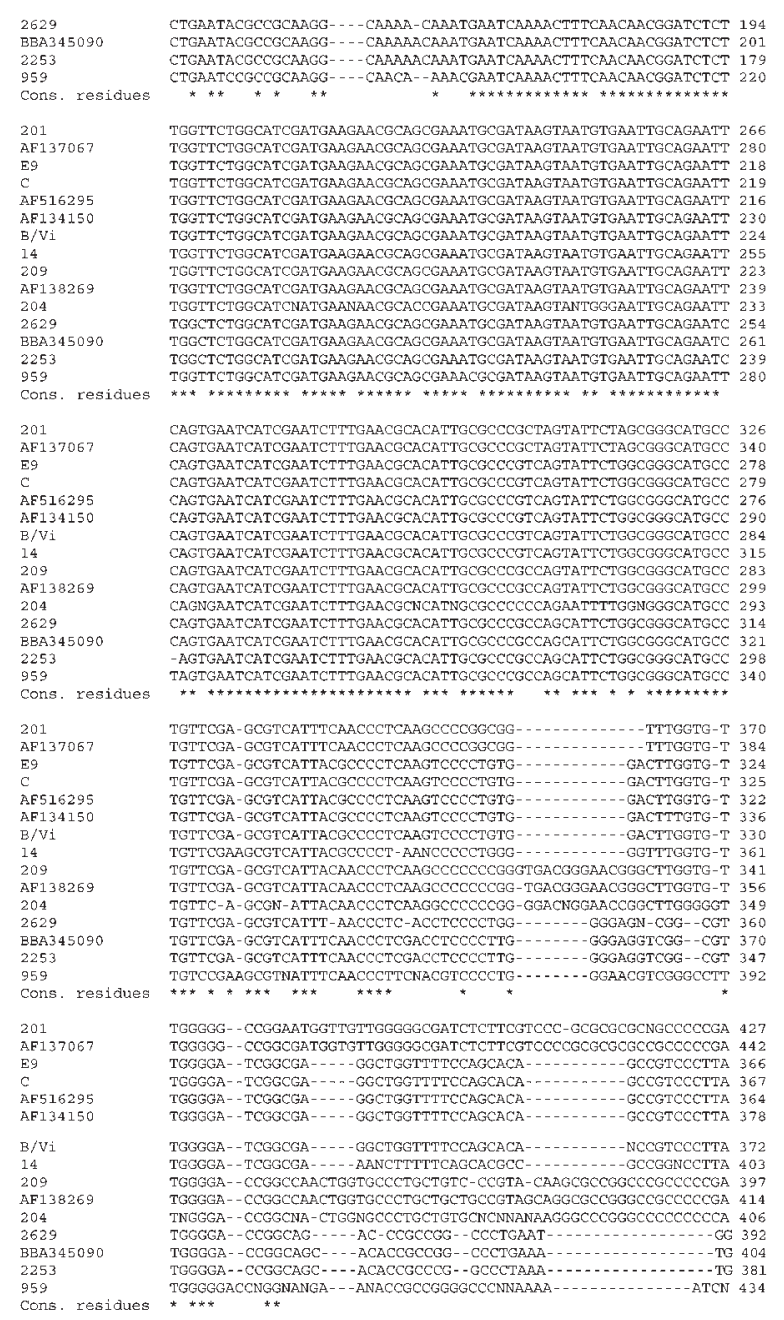

Figure 2 - Alignment of the nucleotide sequences of the ITS1 - 5.8S - ITS2 region of the strains investigated by us (Metarhizium anisopliae var. anisopliae strains $\mathrm{E}_{9}, \mathrm{~B} / \mathrm{Vi}, \mathrm{C}$ and 14; Metarhizium album strain 201; Metarhizium flavoviride strains 204 and 209; Beauveria bassiana strains 959,2253 and 2629) with GenBank ITS sequences for M. a. anisopliae (AF516295 and AF134150), M. album (AF137067), M. flavoviride (AF138269) and B. bassiana (BBA345090). The specific primers ITSMet and ITSMet14 developed by us are indicated by gray boxes. *consensus residues. 


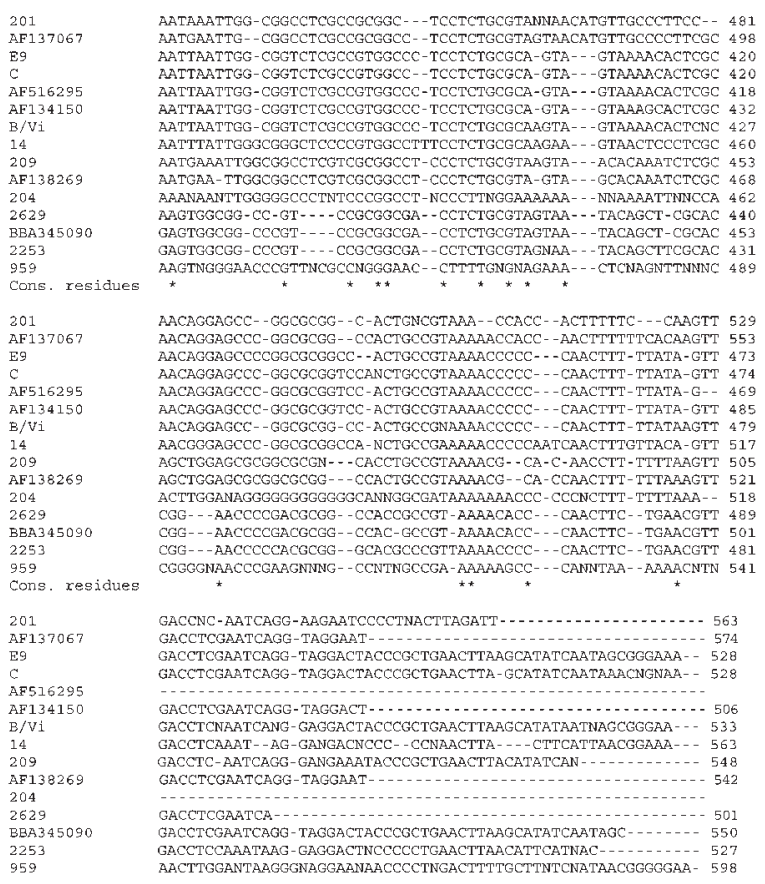

Figure 2 (Cont).

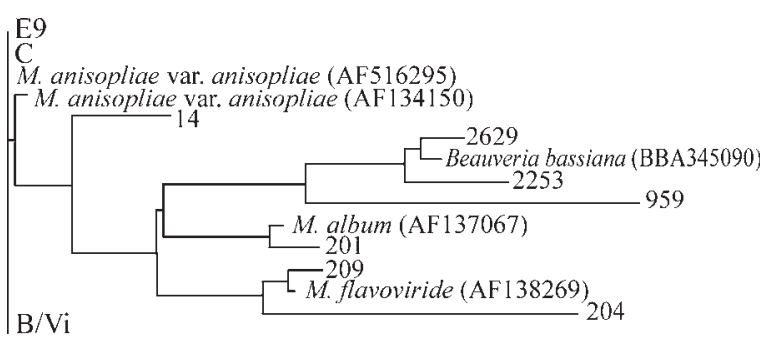

.10

Figure 3 - Phylogenetic analysis of ITS1 - 5.8S - ITS4 rDNA sequences from Metarhizium anisopliae, Metarhizium album, Metarhizium flavoviride and Beauveria bassiana strains based on the Neighbor-joining method. GenBank accession numbers are listed after species names.

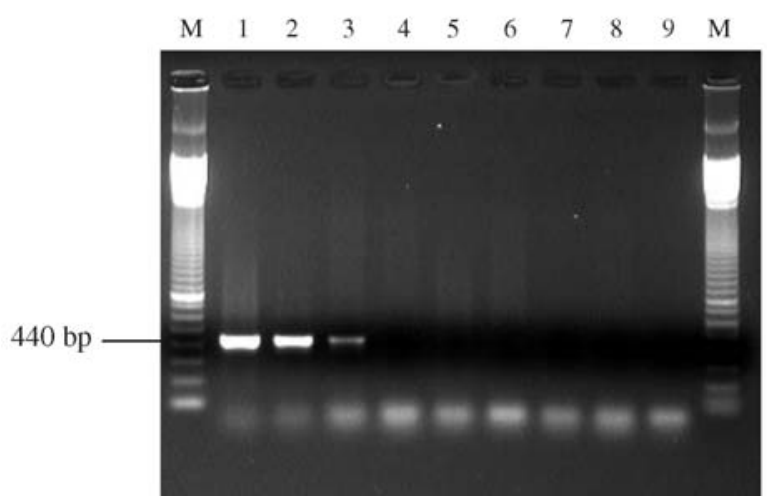

products obtained from infected larvae and pure cultures of the fungi (Figures 5 and 6).

\section{Discussion}

Our PCR-RFLP data showed that the variation in length and restriction sites in the ITS regions could be used to differentiate $M$. a. anisopliae from $M$. album and $M$. flavoviride. The six distinct restriction enzymes tested in this study were able to clearly distinguish the different Metarhizium species investigated. Ribosomal genes and their ITS and IGS spacer regions have been widely used for the identification and differentiation of species (Fouly et al., 1997) as well as in taxonomic (Driver et al., 2000), phylogenetic (Rakotonirainy et al., 1994) and genetic diversity (Anderson et al., 2001; Uetake et al., 2002) studies, with ITS sequences having been reported as being useful for discriminating between different species of fungi (Neuveglise et al., 1994; Fouly et al., 1997; Jensen et al., 2001; Anderson et al., 2001; Thomsen and Jensen, 2002).

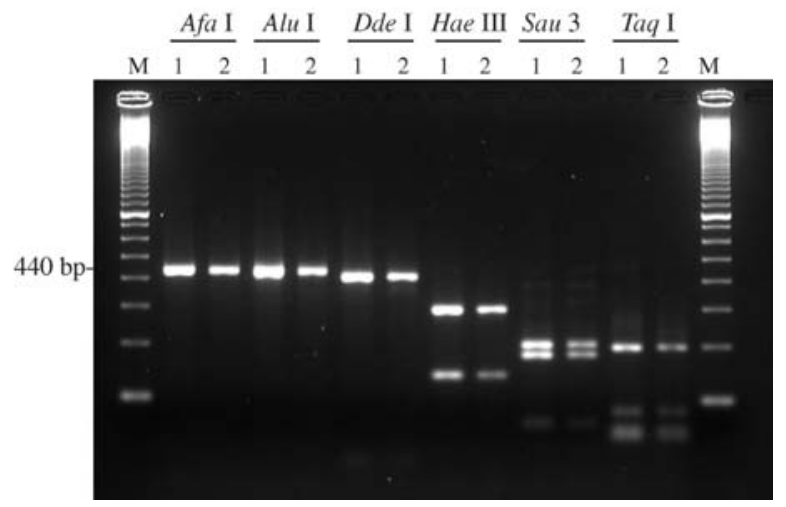

Figure 5 - PCR-RFLP profiles of Metarhizium anisopliae var. anisopliae strain $\mathrm{E}_{9}$ using the ITSMet/ITS4 primer set with the restriction enzymes Afa I, Alu I, Dde I, Hae III, Sau 3A I and Taq I. 1 = DNA from a pure culture of strain $\mathrm{E}_{9} ; 2$ = DNA from larvae infected with strain $\mathrm{E}_{9} . \mathrm{M}=100 \mathrm{bp}$ DNA marker.

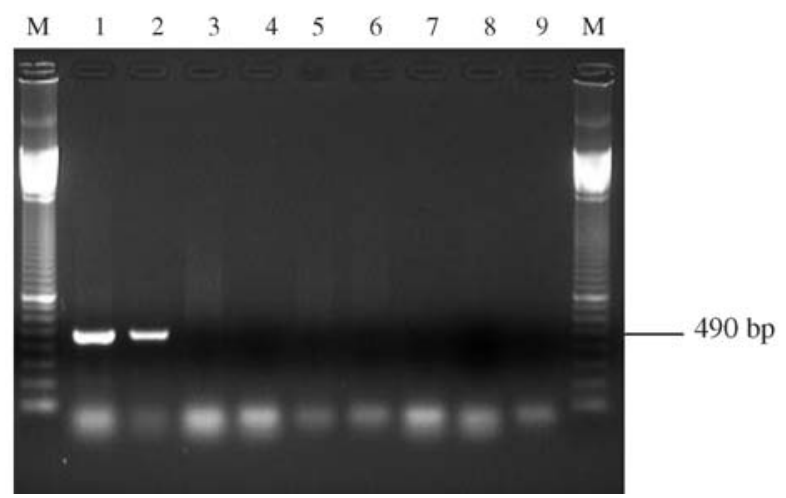

Figure 4 - Amplification of DNA from pure cultures and infected larvae using the primer sets ITSMet/ITS4 (A) and ITS14/ITS4 (B). Primer set A: $1=$ strain $\mathrm{E}_{9} ; 2=$ larvae infected by strain $\mathrm{E}_{9} ; 3=$ strain $14 ; 4=$ larvae infected by strain $14 ; 5=$ strain $201 ; 6=$ strain $204 ; 7=$ strain $959 ; 8=$ non-infected larvae; $9=$ control reaction without DNA. Primer set B: $1=$ strain $14 ; 2=$ larvae infected by strain $14 ; 3=$ strain $\mathrm{E}_{9} ; 4=$ larvae infected by strain $\mathrm{E}_{9} ; 5=$ strain $201 ; 6=\operatorname{strain} 204 ; 7=\operatorname{strain} 959 ; 8=$ non-infected larvae; $9=$ control reaction without DNA. $\mathrm{M}=100$ bp DNA marker. 


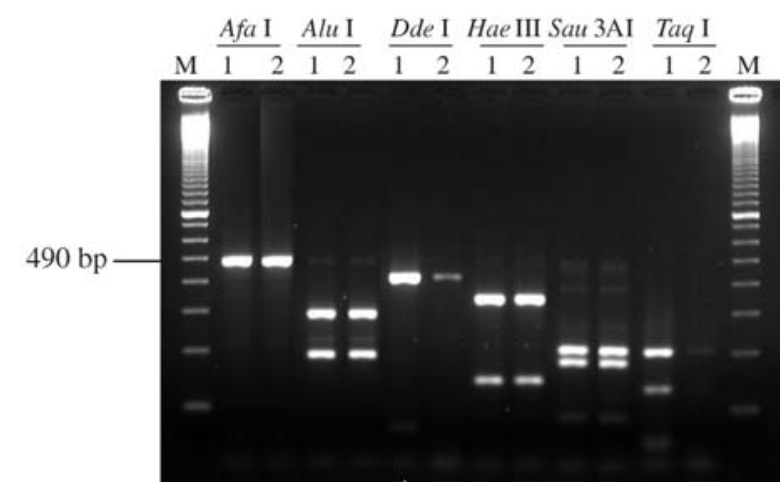

Figure 6 - PCR-RFLP profiles of Metarhizium anisopliae var. anisopliae strain 14 using the ITSMet14/ITS4 primer set with the restriction enzymes Afa I, Alu I, Dde I, Hae III , Sau 3A I and Taq I. 1 = DNA from a pure culture of strain $14 ; 2=$ DNA from larvae infected with strain $14 . \mathrm{M}=100 \mathrm{bp}$ DNA marker

Our ITS1 - 5.8S - ITS2 sequencing data showed variations which allowed us to design specific primers which could not only detect and identify $M$. a. anisopliae but also to differentiate between our Brazilian strains $\left(\mathrm{E}_{9}, \mathrm{~B} / \mathrm{Vi}\right.$ and C) and the Australian strain (strain 14) because the sequence variation of strain 14 was very different from that of the other members of the same species, these sequence variations allowing us to develop a specific primer for strain 14 .

Isolation of PCR-amplifiable DNA from environmental samples is often difficult due to the co-isolation of compounds with the ability to inhibit the PCR (Hegedus and Khachatourians, 1996b). Samples of DNA from plants (Do and Adams, 1991) and fungi (Pfeifer et al., 1993) may retain polysaccharides which can cause problems during amplification and insect cuticles may contain a number of compounds that can act as potent PCR inhibitors (Hackman, 1974). Our extraction protocol produced DNA from infected larva with sufficient purity for direct PCR amplification and although this DNA produced a reduced amount of product in comparison with that produced when DNA from pure cultures was used the amount of product was still sufficient for us to be able to identify the fungal species with which the larva had been infected.

Several fungi have been cited as being potential mycoinsecticides (Samson et al., 1988), although only a few have been intensively investigated and examined at the molecular level (Hegedus and Khachatourians, 1996b). Commercial mycoinsecticides (mycopesticides) require specific and sensitive methods for the identification of the specific fungal strain used during production, such methods being needed not only to ensure strain stability and protect patents but also for use under field conditions for such purposes as making environmental impact assessments.

Specific primers have been developed for the detection and identification of some entomopathogenic fungi such as Beauveria bassiana (Hegedus and Khachatourians, 1996b) and Gliocladium catenulatum (Paavanen-Huhtala et al., 2000). In this study we developed a PCR-based primer set system specific for Metarhizium anisopliae var. anisopliae which can simply, rapidly and securely detect this fungus in Diatraea saccharalis larvae $48 \mathrm{~h}$ after infection without the need to use techniques such as probe hybridization or DNA sequencing.

Our study also showed that M. a. anisopliae, M. album and M. flavoviride can be clearly differentiated using PCR-RFLP of the ITS 1-5.8S-ITS 2 region, supporting the view of Curran et al. (1994) who used amplification and sequencing of the $5.8 \mathrm{~S}$ gene, intergenic regions ITS 1 and ITS 2 and phylogenetic analysis to show that M. anisopliae and M. flavoviride + M. album represent two separate evolutionary lines.

The fact that DNA extracted from infected insects can be rapidly analyzed using our set of primers means that the identification of the entomopathogen fungus $M$. $a$. anisopliae in laboratory and field studies can be used not only to evaluate the efficacy of mycopesticides and indicate when re-application is necessary but also to study the environmental persistence of entomopathogens, such evaluations normally taking a long time because entomopathogenic fungi must be re-isolated and cultured under specific conditions in order for them to be identified by morphological and physiological tests. Our method offers an alternative approach for typing $M$. a. anisopliae strains within infected insects and reduces the need for time-consuming conventional methods. This technique also opens up the possibility of monitoring the environmental impact of $M$. a. anisopliae mycoinsecticides on pollinators and other non-target insects.

\section{Acknowledgments}

The authors are very grateful to Dr. Valéria Maia de Oliveira (CPQBA/UNICAMP, Campinas, SP, Brazil) for help in the phylogenetic analysis, Dr. Enrico De Beni Arrigoni (CTC/COPERSUCAR, Piracicaba, SP, Brazil) for supplying the insects, Irene M. G. Almeida, M.Sc. (Instituto Biológico, Campinas, SP, Brazil) for revision of the manuscript, Cintia Losano, M.Sc., for help in the alignment of sequences, and the undergraduate students Denise M. Balani and Mariana Ferreira for their technical assistance.

\section{References}

Alves SB, Pádua LEM, Azevedo EMVM and Almeida LC (1985) Controle da broca da cana-de-açúcar pelo uso de Beauveria bassiana. Pesq Agrop Bras 20(4):403-406.

Alves SB, Risco SH, Silveira Neto S and Machado Neto R (1984) Pathogenicity of nine isolates of Metarhizium anisopliae (Metsch.) Sorok. to Diatraea saccharalis (Fabr.). Z ang Entom 97:403-406.

Alves SB (2001) RAPD-PCR na distinção de linhagens de Metarhizium anisopliae. VII Simpósio de Controle Biológico, Foz do Iguaçú, Brazil. 
Anderson IC, Chambers SM and Cairney WGJ (2001) ITS-RFLP and ITS sequence diversity in Pisolithus from central and eastern Australian sclerophyll forests. Mycol Res 11:13041312.

Argentina SC (1999) Taxonomia polifásica de Neurospora produtoras de aromas. PhD Thesis, UNICAMP, Campinas, Brazil.

Bidochka MJ, McDonald MA, St. Leger RJ and Roberts DW (1994) Differentiation of species and strains of entomopathogenic by random amplification of polymorphic DNA (RAPD). Curr Gen 25:107-113.

Bindslev L, Oliver RP and Johansen B (2002) In situ PCR for detection and identification of fungal species. Mycol Res 106:277-279.

Curran J, Driver F, Ballard JWO and Milner RJ (1994) Phylogeny of Metarhizium: Analysis of ribosomal DNA sequence data. Mycol Res 98:547-552.

Do N and Adams, RP (1991) A simple technique for removing plant polysaccharide contaminants from DNA. BioTech 10:162-166.

Driver F, Milner RJ and Trueman JWH (2000) A taxonomic revision of Metarhizium based on a phylogenetic analysis of rDNA sequence data. Mycol Res 2:134-150.

Esteve-Zarzoso B, Belloch C, Uruburu F and Querol A (1999) Identification of yeasts by RFLP analysis of the 5.8S rRNA gene and the two ribosomal internal transcribed spacers. Int J Syst Bact 49:329-337.

Fouly H, Wilkinson HT and Chen W (1997) Restriction analysis of internal transcribed spacers and the small subunit gene of ribosomal DNA among four Gaeumannomyces species. Mycologia 89:590-597.

Freire LLC, Costa ABL, Góes LB and Oliveira NT (2001) DNA polymorphism and total protein in mutants of Metarhizium anisopliae var. anisopliae (Metsch.) Sorokin strain $\mathrm{E}_{9}$. Braz J Microb 32:93-97.

Fungaro MHP, Vieira MLC, Pizzirani-Kleiner AA and Azevedo JL (1996) Diversity among soil and insect isolates of Metarhizium anisopliae var. anisopliae detected by RAPD. Lett Appl Microb 22:389-392.

Garber RC and Yoder OC (1983) Isolation of DNA from filamentous fungi and separation into nuclear, mitochondrial, ribosomal, and plasmid components. Anal Bioch 135:416-422.

Hackman RH (1974) Chemistry of the insect cuticle. In: Rockstein M (ed) The Physiology of Insecta, v. VI. Academic Press, New York, pp 215-270.

Hegedus DD and Khachatourians GG (1993a) Construction of cloned DNA probes for the specific detection of the entomopathogenic fungus Beauveria bassiana in grasshoppers. J Invert Path 62: 33-240.

Hegedus DD and Khachatourians GG (1993b) Identification of molecular variants in mitochondrial DNAs of members of the genera Beauveria, Verticillium, Paecilomyces, Tolypocladium, and Metarhizium. Appl Env Microb 59:4283-4288.

Hegedus DD and Khachatourians GG (1996a) Identification and differentiation of the fungus Beauveria bassiana using polymerase chain reaction and single-strand conformation polymorphism analysis. J Invert Path 67:289-299.

Hegedus DD and Khachatourians GG (1996b) Detection of the entomopathogenic fungus Beauveria bassiana within infected migratory grasshoppers (Melanoplus sanguinpes) us- ing polymerase chain reaction and DNA probe. J Invert Path 67:21-27.

Jensen AB, Thomsen L and Eilenberg J (2001) Intraespecific variation and host specificity of Entomophtora muscae sensu stricto isolates revealed by random amplified polimorphic DNA, universal primed PCR, PCR-restriction fragment lenght polymorphism, and conidial morphology. J Invert Path 78:251-259.

Leal SCM, Bertioli DJ, Butt TM and Peberdy JF (1994) Characterization of isolates of the entomopathogenic fungus Metarhizium anisopliae by RAPD-PCR. Mycol Res 98:1077-1081.

Neuveglise C, Brygoo Y, Vercambre B and Riba G (1994) Comparative analysis of molecular and biological characteristics of strains of Beauveria brongniartii isolated from insects. Mycol Res 98:322-328.

Onofre SB, Vargas LRB, Rossato M, Barros NM, Boldo JT, Nunes ARF and Azevedo JL (2002) Controle biológico de pragas na agropecuária, por meio de fungos entomopatogênicos. In: Serafini LA, Barros NM and Azevedo JL (eds) Biotecnologia: Avanços na Agricultura e na Agroindústria, EDUCS, Caxias do Sul, pp 295-317.

Paavanen-Huhtala S, Akinainen H and Yli-Mattila T (2000) Development of strain-specific primers for a strain of Gliocladium catenulatum used in biological control. Eur J Plant Path 106:187-198.

Pfeifer TA and Khachatourians GG (1993) Isolation of DNA from entomopathogenic fungi grown in liquid cultures. J Invert Path 61:113-116.

Pontecorvo G, Roper JA, Hemons JM, Mac Donald KD and Button AWJ (1953) The genetics of Aspergillus nidulans. Adv Gen 5:141-238.

Rakotonirainy MS, Cariou ML, Brygoo Y and Riba G (1994) Phylogenetic relationships within the genus Metarhizium based on 28S rRNA sequences and isozyme comparison. Mycol Res 98:225-230.

Sambrook J, Fritsch EF and Maniatis T (1989) Molecular Cloning: A Laboratory Manual. Cold Spring Harbor Laboratory Press, Cold Spring Harbor, New York, 545 pp.

Samson RA, Evans HC and Latge JP (1988). Atlas of Entomopathogenic Fungi. Springer-Verlag, Netherlands, 187 pp.

Thomsen L and Jensen AB (2002) Application of nested-PCR technique to resting spores from the Entomophthora muscae species complex: implications for analyses of host-pathogen population interactions. Mycologia 94:794-802.

Uetake Y, Arakawa M, Nakamura H, Akahira T, Sayama A, Cheah L-HO, Okabe IO and Matsumoto N (2002) Genetic relationship among violet root rot fungi as revealed by hyphal anastomosis and sequencing of the rDNA ITS regions. Mycol Res 106:156-163.

Urtz BE and Rice WC (1997) RAPD-PCR characterization of Beauveria bassiana isolates from the rice water weevil Lissorhoptrus oryzophilus. Lett Appl Microb 25:405-409.

White TJ, Bruns TD, Lee SB and Taylor JW (1990) Analysis of phylogenetic relationships by amplification and direct sequencing of ribosomal DNA genes. In: Innis DH, Sninsky JJ and White TJ (eds) PCR PROTOCOLS: A Guide to Methods and Applications. Academic Press, New York, pp 315-322.

Editor Associado: Sérgio Olavo Pinto da Costa 